\title{
PREVALENCE OF VIRAL HEPATITIS IN CROATIAN ADULT POPULATION UNDERGOING ROUTINE CHECK-UP, 2010-2011
}

\author{
Tatjana Vilibić-Čavlek¹, Jasmina Kučinar², Sunčanica Ljubin-Sternak², Bernard Kaić3 ${ }^{3}$ Lorena Lazarić- \\ Stefanović ${ }^{2}$, Branko Kolarić ${ }^{4,5}$ \\ ${ }^{1}$ Virology Department, Croatian National Institute of Public Health and School of Medicine University of Zagreb, Zagreb, Croatia \\ ${ }^{2}$ Microbiology Department, Istria County Institute of Public Health, Pula, Croatia \\ ${ }^{3}$ Communicable Disease Epidemiology Service, Croatian National Institute of Public Health, Zagreb, Croatia \\ ${ }^{4}$ Public Health, Social Medicine and Gerontology Service, Zagreb County Institute of Public Health, Zagreb, Croatia \\ ${ }^{5}$ School of Medicine, University of Rijeka, Rijeka, Croatia
}

\begin{abstract}
SUMMARY
Seroprevalence data on viral hepatitis in the general population vary widely. The aim of this study was to determine the prevalence of hepatitis $A(\mathrm{HAV})$, hepatitis $B(\mathrm{HBV})$ and hepatitis $\mathrm{C}(\mathrm{HCV})$ viruses in the general Croatian adult population undergoing routine check-ups. The seroprevalence of anti-HAV, anti-HBC and anti-HCV was $40.5 \%, 7.0 \%$ and $0.9 \%$, respectively. HBsAg was found in $0.7 \%$ and anti-HBs antibodies in $24.4 \%$ of participants. Gender was not associated with HAV, HBV or HCV seropositivity. HAV and HBV seropositivity increased progressively with age (HAV from $11.7 \%$ to $90.4 \%, p<0.001$; HBV from 1.7\% to 15.8\%, $p<0.001$ ). Participants from rural areas showed a significantly higher HBV seroprevalence rate than those from urban areas $(10.7 \%$ vs. $6.1 \%, p=0.007)$. Results of univariate and multiple logistic regression showed that older age was a significant predictor for both HAV and HBV seropositivity while rural place of residence was a significant predictor for HBV seropositivity.
\end{abstract}

Key words: HAV, HBV, HCV, seroprevalence, Croatia

Address for correspondence: T. Vilibić-Čavlek, Virology Department, Croatian National Institute of Public Health, Rockefellerova 12, 10000 Zagreb, Croatia. E-mail: tatjana.vilibic-cavlek@hzjz.hr

\section{INTRODUCTION}

Viral hepatitis infections constitute a global public health problem. More than two billion people are infected with hepatitis A (HAV), hepatitis B (HBV) and hepatitis C (HCV) viruses. HBV and HCV cause 600,000 and 350,000 deaths, respectively, each year (1). In endemic regions, HAV is transmitted primarily through close contact or as result of inadequate sanitation while in low endemic areas HAV infections are commonly linked to travel to endemic areas and to contaminated imported food (2-5). In some European countries, the seroprevalence of HAV varies from $32 \%$ to $88 \%$ (6-10). HBV is transmitted by parenteral or mucosal exposure to infectious blood or secretions, most often through intravenous drug use (IDU) or sexual contact with an infected person. The seroprevalence of HBV in the general population varies widely between European countries. Prevalence of hepatitis B antigen (HBsAg) is reported to range from less than $1 \%$ to $8 \%$, prevalence of hepatitis B core antibodies (anti-HBc) from $1.9 \%$ to $22.6 \%(7,8,11-17)$. The principal mode of HCV transmission is through significant or repeated direct percutaneous exposure to infectious blood or blood products. Seroprevalence of HCV varies in different population groups. Seropositivity is high in high-risk groups such as IDUs, variable among hemodialysis patients and persons with high-risk sexual behaviour and low in voluntary blood donors (16, 18-24).

There are very few published seroepidemiological data on the distribution of viral hepatitis in the general Croatian population.
The aim of this study was to determine the seroprevalence of HAV, HBV and HCV among healthy adults who underwent a routine check-up.

\section{MATERIALS AND METHODS}

\section{Study Population}

During a two-year period (2010-2011), a total of 2,052 consecutive patients aged 20-86 years who underwent a routine check-up (part of physical examination, prior to orthopedic or cardiac surgery, couples undergoing medically assisted reproduction) were tested for the presence of anti-HAV total antibodies, HBsAg, anti-HBs antibodies (anti-HBs), anti-HBc and anti-HCV antibodies, based on the request of the referring physician. No participant showed symptoms of acute hepatitis. There were 924 (45.0\%) males and 1,128 (55.0\%) females from 4 of 20 Croatian counties (three counties in the Croatian mainland and one county on the Adriatic coast). All participants were of Croatian nationality.

\section{Methods}

Anti-HAV, HBsAg, anti-HBs, and anti-HBc total antibodies were detected using an automated enzyme-linked fluorescent assay (Mini Vidas, BioMerieux, Marcy l'Etoile, France). Anti$\mathrm{HAV}$ as well as anti-HBc positive participants were tested for the 
presence of IgM antibodies to confirm or rule out acute HAV and HBV infection (Mini Vidas, BioMerieux, Marcy l'Etoile, France). The results were interpreted according to the manufacturer's recommendations as follows: anti-HAV $<15 \mathrm{mIU} / \mathrm{ml}$ negative; $>15-<20$ equivocal; $>20$ positive; HBsAg test value $<0.10$ negative; $>0.10$ positive, anti-HBs $<8 \mathrm{mIU} / \mathrm{ml}$ negative; $>8$ $<12$ equivocal; $>12$ positive, anti-HBc test value $<1$ positive; $>1-<1.4$ equivocal; $>1.4$ positive.

Anti-HCV antibodies were detected using enzyme-linked immunoassay (Dia Sorin, Sallugia, Italy; Ortho-Clinical Diagnostics, Raritan, NJ). Initially reactive samples were confirmed using third generation LIA test (Innogenetics, Ghent, Belgium). HBV serologic results were classified as follows: active HBV infection (HBsAg positive), past infection (anti-HBs positive/anti-HBc positive) and post-vaccination immunity (anti-HBs positive/ anti-HBc negative). HBsAg positive sera were also tested for hepatitis B envelope antigen (HBeAg) and antibodies (anti-HBe, Mini Vidas, BioMerieux, Marcy l’Etoile, France).

\section{Statistical Analysis}

Difference between groups of categorical variables was assessed using the Fisher exact test. Strength of association between outcome (positive serological test) and explanatory variables (age-group, gender and place of residence) was measured by univariate logistic regression. Confounding and colinearity control was performed by multiple logistic regression. The level of statistical significance was $\alpha=0.05$.

Statistical package STATA/IC ver.11.1. was used to perform statistical analysis.

\section{RESULTS}

Of 749 participants tested, $303(40.5 \%, 95 \% \mathrm{CI}=36.9-44.0)$ showed anti-HAV antibodies. The overall prevalence of HBsAg and anti-HBc (with anti-HBs) was $0.7 \%(95 \% \mathrm{CI}=0.4-1.1$; $15 / 2009)$ and $7.0 \%(95 \% \mathrm{CI}=5.8-8.3 ; 109 / 1552)$, respectively. No HBsAg positive participant was anti-HBc IgM or HBeAg positive. In all HBsAg positive participants anti-HBe antibodies were detected. The prevalence of isolated anti-HBs was $24.4 \%$ $(95 \% \mathrm{CI}=22.3-26.6 ; 379 / 1552)$. Eighteen of 1,930 patients $(0.9 \%, 95 \% \mathrm{CI}=0.5-1.4)$ showed anti-HCV antibodies (Table 1$)$.

The seroprevalence of HAV, HBV and HCV markers according to participant characteristics is shown in Table 2. Gender was not associated with HAV $(p=0.297)$, anti-HBc $(p=0.371)$

Table 1. Seroprevalence of HAV, HBV and HCV in Croatia

\begin{tabular}{|l|c|c|c|}
\hline $\begin{array}{l}\text { Serologic } \\
\text { marker }\end{array}$ & N tested (\%) & N positive (\%) & $\begin{array}{c}95 \% \mathrm{Cl} \\
\text { (positive) }\end{array}$ \\
\hline Anti-HAV & $749(36.5)$ & $303(40.5)$ & $36.9-44.0$ \\
\hline HBsAg & $2009(97.9)$ & $15(0.7)$ & $0.4-1.1$ \\
\hline Anti-HBc* & $1552(75.6)$ & $109(7.0)$ & $5.8-8.3$ \\
\hline Anti-HBs ${ }^{* *}$ & $1552(75.6)$ & $379(24.4)$ & $22.3-26.6$ \\
\hline Anti-HCV & $1930(94.1)$ & $18(0.9)$ & $0.5-1.4$ \\
\hline
\end{tabular}

*Naturally acquired infection

**Post-vaccination immunity

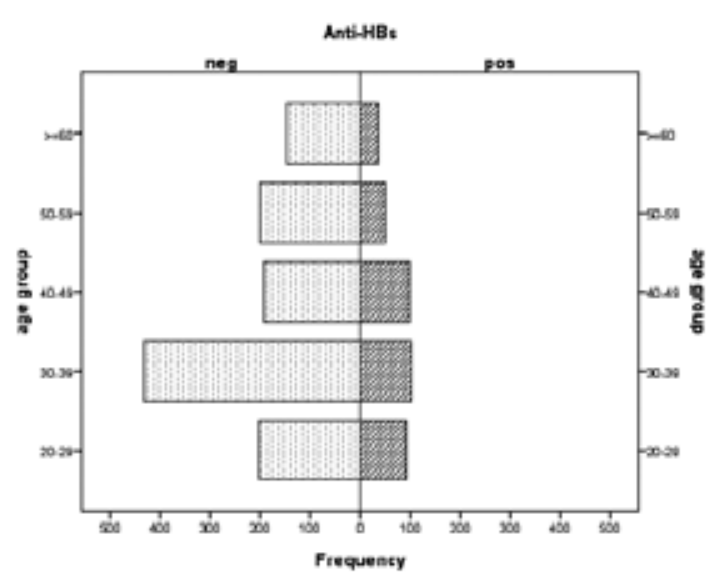

Fig. 1. Prevalence of anti-HBs antibodies according to age groups.

or HCV ( $p=0.476)$ seropositivity. According to age, significant differences in HAV and HBV seropositivity between age groups were found. HAV seroprevalence increased progressively with age from $11.7 \%$ to $90.4 \%$ in $20-29$-year-olds to persons above 60 , respectively $(\mathrm{p}<0.001)$. Anti-HBc seropositivity increased from $1.7 \%$ in the youngest to $15.8 \%$ in the oldest age group $(\mathrm{p}<0.001)$. Age-specific anti-HBs seroprevalence did not follow the same pattern as anti-HBc prevalence. Age groups 20-29 and 40-49 had a significantly higher $(\mathrm{p}<0.001)$ seroprevalence of anti-HBs (31.5\% and 33.9\%, respectively) than the remaining three age groups (30-39 age group 19.1\%, 50-59 age group 20.0\%, and 60+ age group 19.2\%) (Fig. 1). HCV seroprevalence did not differ among age groups $(0.7-1.7 \%, \mathrm{p}=0.081)$. Participants residing in rural areas showed significantly higher HBV seropositivity than participants residing in urban areas $(10.7 \%$ vs. $6.1 \%, p=0.007)$. There was no difference in HAV $(p=0.463)$ or HCV $(p=0.553)$ seroprevalence according to the place of residence.

Results of univariate logistic regression (Table 3) suggest a steady increase of strength of association with age for both HAV and HBV seropositivity. Rural place of residence was a significant predictor for HBV seropositivity $(\mathrm{OR}=0.543,95 \%$ $\mathrm{CI}=0.355-0.831)$.

Multiple logistic regression showed that age was a significant predictor for both $\mathrm{HAV}(\mathrm{OR}=1.116,95 \% \mathrm{CI}=1.098-1.134)$ and HBV $(\mathrm{OR}=1.040,95 \% \mathrm{CI}=1.027-1.054)$ seropositivity, while living in rural areas was a significant predictor for HBV seropositivity $(\mathrm{OR}=0.62,95 \% \mathrm{CI}=0.402-0.958)$ (Table 4$)$.

\section{DISCUSSION}

To our knowledge, this is the first report on the seroprevalence of viral hepatitis performed on a large sample in the general Croatian population. In the past twenty years several similar studies were conducted in Croatia but only in specific areas (25) or among certain population groups, such as blood donors (23), IDUs $(19,20,26)$, persons with high-risk sexual behaviour (22, $27)$, and prison population $(28,29)$.

In this study, the overall seroprevalence of HAV was found to be $40.5 \%$, echoing seroprevalence studies in other developed countries $(3,6)$. It is not possible to distinguish post-vaccination 
Table 2. Seroprevalence of HAV, HBV and HCV according to participants characteristics

\begin{tabular}{|c|c|c|c|c|c|c|c|c|c|}
\hline \multirow{2}{*}{ Characteristic } & \multicolumn{3}{|c|}{ Anti-HAV } & \multicolumn{3}{|c|}{ Anti-HBc } & \multicolumn{3}{|c|}{ Anti-HCV } \\
\hline & N pos/N (\%) & $95 \% \mathrm{Cl}$ & $p$ & $\mathrm{~N}$ pos/N (\%) & $95 \% \mathrm{Cl}$ & $p$ & N pos/N (\%) & $95 \% \mathrm{Cl}$ & $p$ \\
\hline Gender & & & 0.297 & & & 0.371 & & & 0.476 \\
\hline Male & 150/389 (38.6) & $33.7-44.3$ & & $58 / 757(7.7)$ & $5.8-9.6$ & & 10/863 (1.2) & $0.4-1.9$ & \\
\hline Female & $153 / 360(42.5)$ & $37.4-47.6$ & & $51 / 795(6.4)$ & $4.7-8.1$ & & $8 / 1067(0.7)$ & $0.2-1.3$ & \\
\hline Age (years) & & & $<0.001$ & & & $<0.001$ & & & 0.081 \\
\hline $20-29$ & 15/128 (11.7) & 6.1-17.3 & & $5 / 295(1.7)$ & $0.2-3.2$ & & $1 / 324(0.3)$ & $0.1-0.9$ & \\
\hline 30-39 & $51 / 263(19.4)$ & $14.6-24.2$ & & $24 / 533(4.5)$ & $2.7-6.3$ & & $10 / 605(1.7)$ & $0.6-2.7$ & \\
\hline $40-49$ & $57 / 129(44.2)$ & $35.6-52.8$ & & 27/291 (9.3) & $5.9-12.6$ & & 0/304 (0) & $N / A-1.2$ & \\
\hline $50-59$ & $95 / 135(70.4)$ & $62.7-78.1$ & & $24 / 250(9.6)$ & 5.9-13.3 & & 2/278 (0.7) & $0.1-2.5$ & \\
\hline $60+$ & $85 / 94(90.4)$ & $84.5-96.4$ & & 29/183 (15.8) & $10.6-21.1$ & & $5 / 419(1.2)$ & $0.2-2.2$ & \\
\hline Area of residence & & & 0.463 & & & 0.007 & & & 0.553 \\
\hline Urban & 236/594 (39.7) & $35.8-43.7$ & & $75 / 1233(6.1)$ & $4.7-7.4$ & & $16 / 1546(1.0)$ & $0.5-1.5$ & \\
\hline Rural & $67 / 155$ (43.2) & $35.4-51.0$ & & $34 / 319(10.7)$ & 7.3-14.0 & & 2/384 (0.5) & $0.1-1.9$ & \\
\hline
\end{tabular}

N/A = not applicable

Table 3. Univariate logistic regression for the risk of HAV, HBV and HCV seropositivity

\begin{tabular}{|c|c|c|c|c|c|c|}
\hline Characteristic & Anti-HAV OR & $95 \% \mathrm{Cl}$ & Anti-HBc OR & $95 \% \mathrm{Cl}$ & Anti-HCV OR & $95 \% \mathrm{Cl}$ \\
\hline Male vs. female gender & 0.849 & $0.634-1.137$ & 1.21 & $0.819-1.788$ & 1.552 & $0.61-3.949$ \\
\hline \multicolumn{7}{|l|}{ Age group } \\
\hline $20-29$ & 1 (referent group) & $\mathrm{N} / \mathrm{A}$ & 1 & $N / A$ & 1 & $N / A$ \\
\hline 30-39 & 1.812 & $0.976-3.367$ & $2.734^{\star}$ & $1.032-7.244$ & 5.429 & $0.692-42.596$ \\
\hline $40-49$ & $5.964^{*}$ & $3.142-11.321$ & $5.932^{\star}$ & $2.251-15.627$ & $\mathrm{~N} / \mathrm{A}(0$ cases $)$ & $\mathrm{N} / \mathrm{A}$ \\
\hline $50-59$ & $17.892^{\star}$ & $9.311-34.379$ & $6.159^{*}$ & $2.314-16.396$ & 2.341 & $0.211-25.951$ \\
\hline $60+$ & $71.148^{\star}$ & $29.719-170.333$ & $10.922^{\star}$ & $4.145-28.783$ & 3.901 & $0.454-33.555$ \\
\hline $\begin{array}{l}\text { Urban vs. } \\
\text { rural residence }\end{array}$ & 0.866 & $0.605-1.238$ & $0.543^{*}$ & $0.355-0.831$ & 1.997 & $0.457-8.724$ \\
\hline
\end{tabular}

N/A = not applicable

*significant at 0.05 leve

Table 4. Multiple logistic regression for the risk of HAV, HBV and HCV seropositivity

\begin{tabular}{|l|c|c|c|c|c|c|}
\hline Characteristic & Anti-HAV OR & $95 \% \mathrm{Cl}$ & Anti-HBc OR & $95 \% \mathrm{Cl}$ & Anti-HCV OR & 95\% Cl \\
\hline Male vs. female gender & 0.929 & $0.649-1.329$ & 1.307 & $0.877-1.946$ & 1.608 & $0.629-4.112$ \\
\hline Age (one year increase) & $1.116^{*}$ & $1.098-1.134$ & $1.040^{\star}$ & $1.027-1.054$ & 1.008 & $0.980-1.037$ \\
\hline Urban vs. rural residence & 0.718 & $0.465-1.107$ & $0.620^{\star}$ & $0.402-0.958$ & 2.093 & $0.477-9.187$ \\
\hline
\end{tabular}

*significant at 0.05 level

immunity from immunity following natural infection by serologic testing. According to the Croatian National Institute of Public Health Immunization Department data, hepatitis A vaccine consumption in Croatia is very low, with less than a thousand vaccine doses used annually. Such a low vaccination rate (hepatitis A vaccine usage has been increasing in the last decade, reaching only 1.5 dose per 10,000 population annually in 2012) cannot explain the seroprevalence found in our study. Since vaccination rates against HAV in Croatia are very low, the immunity is most probably the result of naturally acquired infection. Although some studies found men to be generally at greater risk of HAV infection than women $(7,8)$, we found no difference in HAV seropositivity between men and women ( $38.6 \%$ vs. $42.5 \%, \mathrm{p}=0.297)$. Similarly to other published studies $(6,8,10)$, HAV seropositivity was strongly age-dependent and increased progressively from $17.3 \%$ in $20-29$-year-olds to $90.4 \%$ in participants above 60 ( $\mathrm{p}<0.001$ ). Older people had a greater probability of becoming infected with HAV due to poorer hygiene and sanitation in the past (30). In some studies, higher seroprevalence rates have been correlated with persons residing in rural regions (8). In our study, there was no significant difference in HAV seropositivity according to the place of residence (43.2\% in participants residing in rural areas and $39.7 \%$ in those residing in urban areas, $p=0.463$ ).

The prevalence of chronic HBV infection (HBsAg positive) in the general population varies among European countries. The HBsAg carrier rates are reported to be less than $1 \%$ in the Netherlands (12), France (13), Italy (15), Spain (31), the Czech Republic (32), Slovenia, and Hungary (33). Higher prevalence 
rates were found in Kosovo 2.4\% (8), Greece 3.4\% (14), Bulgaria 4.0\% (33), and Romania 5.6\% (16). HBsAg prevalence among Croatian adult patients who underwent routine screening or a preoperative check-up was $0.7 \%$. Similar results were reported by Polish authors who tested a group of surgical and gynecologic patients and found HBsAg in $0.6 \%$ of patients (34).

In this study, naturally acquired HBV infection (anti-HBs positive/anti-HBc positive) was documented in $7.0 \%$ of participants. The HBV seroprevalence in Croatian patients is comparable to that of Luxembourg (6.4\%) (6), France (7.3\%) (13), Italy (8.4\%) (11), and Spain (8.7\%) (31), while Kosovo and Greece showed much higher seropositivity rates (18.43\% and $22.6 \%$, respectively) $(8,17)$. Our results showed no difference in HBV seropositivity between males and females $(7.7 \%$ vs. $6.4 \%, p=0.371)$ while in a study conducted in Greece, significantly higher anti-HBc rates were found in men, compared to women (17). Like other studies $(6,8,16,17,31)$, the present results showed that the prevalence of anti-HBc antibodies tends to increase with age (1.7-15.8\%, $\mathrm{p}<0.001)$. This older population most likely came into contact with HBV before it was recognized through hospital care, exposure to different medical procedures or blood transfusions (17).

There is only one published study on the seroprevalence of HBV in a limited area, in northeast Croatia (Community of Slavonski Brod), from 1994 (25), showing two times higher HBsAg and anti-HBc prevalence than found in our study $(1.8 \%$ and $13.7 \%$, respectively). Echoing the present findings, there was no difference in HBV prevalence among males and females. However, in contrast to the study from Slavonski Brod, our results showed that rural areas had a significantly higher HBV infection rate than urban ones $(10.7 \%$ vs. $6.1 \%, \mathrm{p}=0.007)$. Similar results have been reported by Greek authors (17).

In this study, post-vaccination immunity against HBV (antiHBs alone) was documented in $24.4 \%$ of participants, which is comparable to that in Italy (23.8\%) (11) and France (22.2\%) (13). Age-specific prevalence of anti-HBs is relatively high (31.5\%) in the 20-29 age group, as expected, since about $40 \%$ persons in this age group should have been vaccinated against hepatitis $\mathrm{B}$ according to the National Immunization Program. Immunization against HBV was introduced in Croatia in 1999 at the age of 12. Additionally, very low prevalence of anti-HBc in this age group (1.7\%) confirms that the prevalence of anti-HBs in the 20-29 age group is primarily the result of vaccination. The crude incidence of hepatitis B in the last five years has decreased about $40 \%$, compared to the pre-vaccination period, and the greatest age-specific reduction of $>90 \%$ is observed in the 15-19 age group, followed by the 20-29 age group which experienced $70 \%$ reduction in hepatitis B incidence (35). This disproportionate reduction in agespecific incidence is clearly the result of universal vaccination and is reflected by the high seroprevalence of anti-HBs in the 20-29 age group in our sample. The highest prevalence of anti-HBs in the 40-49 age group (33.9\%) is somewhat unexpected, since the seroprevalence of anti-HBc shows a steady increase with age. However, as we do not have any information on vaccination status of the study subjects, we cannot exclude the possibility that a significant proportion of persons in this age group is vaccinated against hepatitis $\mathrm{B}$ due to their occupational requirements, as contacts of HBV carriers or as members of some other risk groups.

A low prevalence of anti-HCV (0.9\%) suggests that HCV infection is uncommon in both urban $(1.0 \%)$ and rural $(0.5 \%)$ general Croatian population. The similar prevalences of HCV (0.5-1.1\%) have been reported by the majority of European countries $(8,11-13,17,34)$. However, some countries such as Italy and Romania reported higher seroprevalence rates $(2.7 \%$ and $4.5 \%$, respectively) $(16,36)$. Two Croatian studies published in 2000 and 2009 have shown that $0.035 \%$ of blood donors (23) and $0.5 \%$ of pregnant women are seropositive to HCV (22).

In this study, anti-HCV positivity was similar in males (1.2\%) and females $(0.7 \%)$ as in Italy $(11,15)$. In contrast, Romanian authors reported higher HCV seropositivity rates among females compared to males $(16,37)$.

In addition, we found no significant difference in HCV seroprevalence among age groups $(0.7-1.7 \%, \mathrm{p}=0.081)$ although in some studies seropositivity increased significantly with age (15, 16, 35, 36). Moreover, Italian authors reported a bimodal distribution of HCV with the highest prevalence in subjects over 75 years of age (11). Seroprevalence of anti-HCV could be considered bimodal in our sample as well, with the highest prevalence in the 30-39 age group. The differences in age-specific prevalence, however, are not found to be significant.

In a Romanian study, significantly higher seropositivity rates were documented in inhabitants of rural area compared to subjects living in urban and metropolitan areas (37). Our study found no association of HCV seropositivity with the place of residence.

In conclusion, the results of this large seroprevalence study in the Croatian adult population undergoing routine check-ups show that the seroprevalence rate of HAV (40.5\%), HBV (HBsAg $0.7 \%$, anti-HBc $7.0 \%)$ and HCV (0.9\%) seems to echo the seroprevalence rates of many European countries. Older age was a statistically significant risk factor for both HAV and HBV seropositivity while rural place of residence was a significant predictor for HBV seropositivity. Gender does not play an important role for HAV, HBV or HCV seropositivity in the general population.

Our finding on seroprevalence of HAV and HBV (anti-HBc) increasing with age is in accordance with the observed decrease in the incidence of these diseases in the population. Hepatitis A incidence decreased at a steady rate from an average of 100 per 100,000 population in the 1950 s to less than 1 per 100,000 in the last decade (35), which explains the significant difference in seroprevalence rates by age group.

The average incidence of hepatitis B (acute, chronic and asymptomatic HBsAg carriage together) dropped from 10 per 100,000 population in the late 1970s (reporting introduced in 1976) to 5 per 100,000 in the last five years (35). Age-specific seroprevalence of HBV infection is thus believed to reflect changing epidemiology of hepatitis B characterized by a decrease in incidence.

Information regarding the status of viral hepatitis immunity is useful in the planning of health care and infection control measures.

\section{REFERENCES}

1. Hatzakis A, Wait S, Bruix J, Buti M, Carballo M, Cavaleri M, et al. The state of hepatitis B and C in Europe: report from the hepatitis B and C summit conference. J Viral Hepat. 2011 Sep;18 Suppl 1:1-16.

2. Daniels D, Grytdal S, Wasley A; Centers for Disease Control and Prevention (CDC). Surveillance for acute viral hepatitis - United States, 2007. MMWR Surveill Summ. 2009 May 22;58(3):1-27. 
3. Bernard H, Frank C. Cluster of hepatitis A cases among travellers returning from Egypt, Germany, September through November 2008. Euro Surveill. 2009 Jan 22;14(3). pii: 19096.

4. Petrignani M, Harms M, Verhoef L, van Hunen R, Swaan C, van Steenbergen J, et al. Update: a food-borne outbreak of hepatitis A in the Netherlands related to semi-dried tomatoes in oil, January-February 2010. Euro Surveill. 2010 May 20;15(20). pii: 19572.

5. Gillesberg Lassen S, Soborg B, Midgley SE, Steens A, Vold L, SteneJohansen K, et al. Ongoing multi-strain food-borne hepatitis A outbreak with frozen berries as suspected vehicle: four Nordic countries affected, October 2012 to April 2013. Euro Surveill. 2013 Apr 25;18(17):20467.

6. Mossong J, Putz L, Patiny S, Schneider F. Seroepidemiology of hepatitis A and hepatitis B virus in Luxembourg. Epidemiol Infect. 2006 Aug;134(4):808-13.

7. Chlíbek R, Čečetková B, Smetana J, Prymula R, Kohl I. Seroprevalence of antibodies against hepatitis A virus and hepatitis B virus in nonvaccinated adult population over 40 years of age. Epidemiol Mikrobiol Imunol. 2006 Aug;55(3):99-104. (In Czech.)

8. Quaglio G, Ramadani N, Pattaro C, Cami A, Dentico P, Volpe A, et al. Prevalence and risk factors for viral hepatitis in the Kosovarian population: implications for health policy. J Med Virol. 2008 May;80(5):833-40.

9. Vatev NT, Atanasova MV, Stoilova YD, Chervenyakova TP, Troyancheva MG. Seroprevalence of hepatitis A viral infection in Plovdiv, Bulgaria. Folia Med (Plovdiv). 2009 Jan-Mar;51(1):70-3.

10. Vilibic-Cavlek T, Kucinar J, Ljubin-Sternak S, Kolaric B. Seroepidemiology of hepatitis A in the Croatian population. Hepat Mon. 2011 Dec;11(12):997-9.

11. Fabris P, Baldo V, Baldovin T, Bellotto E, Rassu M, Trivello R, et al. Changing epidemiology of HCV and HBV infections in Northern Italy: a survey in the general population. J Clin Gastroenterol. 2008 MayJun;42(5):527-32.

12. Baaten GG, Sonder GJ, Dukers NH, Coutinho RA, Van den Hoek JA Population-based study on the seroprevalence of hepatitis A, B, and C virus infection in Amsterdam, 2004. J Med Virol. 2007 Dec;79(12):180210 .

13. Meffre C, Le Strat Y, Delarocque-Astagneau E, Dubois F, Antona D, Lemasson JM, et al. Prevalence of hepatitis B and hepatitis $\mathrm{C}$ virus infections in France in 2004: social factors are important predictors after adjusting for known risk factors. J Med Virol. 2010 Apr;82(4):546-55.

14. Zacharakis G, Kotsiou S, Papoutselis M, Vafiadis N, Tzara F, Pouliou E, et al. Changes in the epidemiology of hepatitis B virus infection following the implementation of immunisation programmes in northeastern Greece. Euro Surveill. 2009 Aug 13;14(32). pii: 19297.

15. Cozzolongo R, Osella AR, Elba S, Petruzzi J, Buongiorno G, Giannuzzi V, et al.; NUTRIHEP Collaborating Group. Epidemiology of HCV infection in the general population: a survey in a southern Italian town. Am J Gastroenterol. 2009 Nov;104(11):2740-6.

16. Voiculescu M, Iliescu L, Ionescu C, Micu L, Ismail G, Zilisteanu D, et al. A cross-sectional epidemiological study of HBV, HCV, HDV and HEV prevalence in the SubCarpathian and South-Eastern regions of Romania. J Gastrointestin Liver Dis. 2010 Mar;19(1):43-8.

17. Gogos CA, Fouka KP, Nikiforidis G, Avgeridis K, Sakellaropoulos G, Bassaris H, et al. Prevalence of hepatitis B and C virus infection in the general population and selected groups in South-Western Greece. Eur J Epidemiol. 2003;18(6):551-7.

18. Nelson PK, Mathers BM, Cowie B, Hagan H, Des Jarlais D, Horyniak $\mathrm{D}$, et al. Global epidemiology of hepatitis B and hepatitis $\mathrm{C}$ in people who inject drugs: results of systematic reviews. Lancet. 2011 Aug 13;378(9791):571-83

19. Kolovrat A, Jurišić I, Marić Z, Cvitković A. Prevalence of hepatitis B, hepatitis $\mathrm{C}$ and HIV among injecting drug users treated outpatiently and in therapeutic community in Brod-Posavina County, Croatia. Acta Med Croatica. 2010 Oct;64(4):287-96. (In Croatian.)

20. Vilibić-Čavlek T, Marić J, Katičić L, Kolarić B. Hepatitis C virus antibody status, sociodemographic characteristics, and risk behaviour among injecting drug users in Croatia. Cent Eur J Public Health. 2011 Mar;19(1):26-9.
21. Bosevska G, Kuzmanovska G, Sikole A, Dzekova-Vidimilski P, Polenakovic $M$. Screening for hepatitis B, C and HIV infection among patients on haemodialysis (cross sectional analysis among patients from two dialysis units in the period January to July 2005). Prilozi. 2009 Dec;30(2):159-74

22. Vilibic Cavlek T, Gjenero Margan I, Zidovec Lepej S, Kolaric B, Vince A. Seroprevalence, risk factors, and hepatitis $C$ virus genotypes in groups with high-risk sexual behavior in Croatia. J Med Virol. 2009 Aug;81(8):1348-53.

23. Grgičević D, Balija M, Pirc-Tiljak D, Mihaljević I, Gjenero-Margan I, Zupančić-Šalek S, et al. Decreasing risk of viral transfusion-transmitted diseases in Croatia. Croat Med J. 2000 Jun;41(2):191-6.

24. Kolarić B, Štajduhar D, Gajnik D, Rukavina T, Wiessing L. Seroprevalence of blood-borne infections and population sizes estimates in a population of injecting drug users in Croatia. Cent Eur J Public Health. 2010 Jun;18(2):104-9.

25. Jelić O, Jelić D, Balen I, Jelić A, Jelić N, Mihaljević I. Prevalence of markers of hepatitis $\mathrm{B}$ virus infection among the general population of the municipality of Slavonski Brod. Acta Med Croatica. 1994;48(3):111-6.

26. Medić A, Dželalija B, Sonicki Z, Zekanović D. Characteristics of hepatitis $\mathrm{C}$ infection in injecting drug users in Zadar County, Croatia. Coll Antropol. 2008 Sep;32(3):697-702.

27. Bozicevic I, Dakovic Rode O, Zidovec Lepej S, Johnston LG, Stulhofer A, Dominkovic Z, et al. Prevalence of sexually transmitted infections among men who have sex with men in Zagreb, Croatia. AIDS Behav. 2009 Apr;13(2):303-9.

28. Burek V, Horvat J, Butorac K, Mikulić R. Viral hepatitis B, C and HIV infection in Croatian prisons. Epidemiol Infect. 2010 Nov;138(11):161020.

29. Vilibic-Cavlek T, Gjenero-Margan I, Retkovac B, Kolaric B, Bisko A Banozic-Blagus Z, et al. Sociodemographic characteristics and risk behaviors for HIV, hepatitis B and hepatitis C virus infection among Croatian male prisoners. Int J Prison Health. 2011;7(1):28-31.

30. Domínguez A, Bruguera M, Plans P, Espuñes J, Costa J, Plasencia A, et al. Declining hepatitis A seroprevalence in adults in Catalonia (Spain): a population-based study. BMC Infect Dis. 2007 Jul 4;7:73.

31. Salleras L, Domínguez A, Bruguera M, Plans P, Costa J, Cardeñosa N, et al. Declining prevalence of hepatitis B virus infection in Catalonia (Spain) 12 years after the introduction of universal vaccination. Vaccine. 2007 Dec 17;25(52):8726-31.

32. Němeček V, Č́stková J, Fritz P, Linhartová A, Švandová E, Šrámová H, et al. The 2001 serological survey in the Czech Republic - viral hepatitis. Cent Eur J Public Health. 2003 Dec;11 Suppl:S54-61.

33. Eurohep.net. Surveillance of vaccine preventable hepatitis [Internet] CEV/ESOC; c2002 [cited 2014 Feb 25]. Available from: http://www. eurohep.net/.

34. Gańczak M, Szych Z. Rationale against preoperative screening for HIV in Polish hospitals: a prevalence study of anti-HIV in contrast to antihepatitis $\mathrm{C}$ virus and hepatitis B surface antigen. Infect Control Hosp Epidemiol. 2009 Dec;30(12):1227-9.

35. Baklaić Ž, Dečković-Vukres V, Kuzman M, editors. Croatian health service yearbook 2010 [Internet]. Zagreb: Croatian National Institute of Public Health; 2011 [cited 2013 Jul 2]. Available from: http://hzjz.hr/ wp-centent/uploads/2013/11/ljetopis_2011.pdf.

36. Ansaldi F, Bruzzone B, Salmaso S, Rota MC, Durando P, Gasparini R, et al. Different seroprevalence and molecular epidemiology patterns of hepatitis C virus infection in Italy. J Med Virol. 2005 Jul;76(3):327-32.

37. Gheorghe L, Csiki IE, Iacob S, Gheorghe C, Smira G, Regep L. The prevalence and risk factors of hepatitis $C$ virus infection in adult population in Romania: a nationwide survey 2006 - 2008. J Gastrointestin Liver Dis. 2010 Dec;19(4):373-9. 